\title{
ОСОБЛИВОСТІ НАВЧАННЯ СТУДЕНТІВ СТОМАТОЛОГІЧНОГО ФАКУЛЬТЕТУ НА МОДУЛІ “МІСЦЕВЕ ЗНЕБОЛЕННЯ В СТОМАТОЛОГІї"
}

\author{
А. Г. Гулюк, В. Г. Крикляс, Н. Б. Дмитрісва, О. О. Фаренюк \\ Одеський національний медичний університет
}

\section{PECULIARITIES OF STUDENTS' STUDYING IN FACULTY OF DENTAL UNIT ON THE MODULE "LOCAL ANESTHESIA IN DENTISTRY"}

\author{
A. H. Huliuk, V. H. Kryklias, N. B. Dmytriyeva, O. O. Fareniuk \\ Odessa National Medical University
}

\begin{abstract}
У статті наведено досвід викладання модуля “Місцеве знеболення в стоматології” на кафедрі хірургічної стоматології Одеського національного медичного університету з використанням тренажера для проведення периферичних і центральних провідникових анестезій.
\end{abstract}

The article presents the experience of teaching module "Local anesthesia in dentistry" at the Department of Operative Dentistry of Odessa National Medical University, using the simulator for the peripheral and central anesthesia.

Вступ. В теперішній час в житті, в медицині, і зокрема, в стоматології відбулися великі зміни. 3’явилась велика кількість приватних клінік, кабінетів, пацієнти отримали можливість вибирати собі лікаря. Пацієнти хочуть отримувати якісну і безболісну допомогу. Починати надання стоматологічної допомоги такого рівня необхідно при навчанні студентів стоматологічного факультету з третього курсу, коли вони приходять на кафедру хірургічної стоматології на модуль "Місцеве знеболення в стоматології”.

Основна частина. Для правильного проведення анестезії треба мати хорошу теоретичну підготовку. Теоретична підготовка включає:

- знання нормальної анатомії (анатомія трійчастого нерва) і топографічної анатомії (треба чітко уявляти топографічні особливості ділянки, де проводять анестезію, знати чітко місце уколу голки, напрям руху голки, місцезнаходження цільового пункту);

- знати фармакодинамічні і фармакокінетичні характеристики знеболювального розчину, який вводять пацієнту;

- вміти оцінити загальний стан пацієнта, враховуючи супутню соматичну патологію і вікові особливості пацієнта;

- прогнозувати можливі місцеві і загальні ускладнення при проведенні анестезії, проводити заходи, направлені на профілактику цих ускладнень, знати заходи невідкладної допомоги при виникненні можливих ускладнень.

Відповідно студентам необхідні знання, отримані на кафедрах нормальної анатомії, топографічної анатомії, фармакології, внутрішніх хвороб. Після цього необхідно ознайомитись і опрацювати кілька монографій 3 анестезій у стоматології (2-3) і ознайомитися з сучасними статтями в журналах стоматологічного профілю (4-5 статей). Для упорядкування знань за даними темами студенти використовують цифровий варіант лекцій. Після засвоєння теоретичних знань ми переходимо до перевірки цих знань шляхом опитування і тестових контролів. Після того, як проведена оцінка теоретичної підготовки кожного студента, ми переходимо до відпрацювання практичних навичок. Відробка практичних навичок починається з того, що викладач демонструє студентам різні види шприців (одноразові типу “Люєр”, карпульні багаторазові і карпульні одноразові). Потім відпрацьовують навички набору розчинів з ампул в шприци одноразові типу “Люєр” (звичайно використовуються для цього прострочені розчини анестетиків або інші розчини). Також відпрацьовують навички введення карпул анестетика в різні види багаторазових і одноразових карпульних шприців і накручування голок на канюлі багаторазових карпульних шприців. Потім на моделях щелеп відпрацьовуємо методику пошуку проекції верхівок коренів зубів для проведення інфільтраційної анестезії.

\footnotetext{
() А. Г. Гулюк, В. Г. Крикляс, Н. Б. Дмитрієва, О. О. Фаренюк
} 
Моделі щелеп виготовляються в зуботехнічній лабораторії з супергіпсу. Для імітації м'яких тканин зверху супергіпсу наклеюють поролон товщиною 2 мм і білу бавовняну тканину. Для відпрацювання методик інфільтраційної анестезії відпрацьовані карпули з-під анестетиків заповнюють водою і проводять ін'єкції в імітацію м'яких тканин на моделях щелеп в ділянці зубів, які необхідно знеболити.

Для відпрацювання навичок провідникового знеболення нами розроблений і виготовлений тренажер для відпрацювання різних видів центральних та периферичних провідникових анестезій. Для виготовлення цього тренажера був взятий натуральний череп людини. По місцях виходу трійчастого нерва (цільові пункти проведення центральних і периферичних провідникових анестезій) були напаяні невеличкі пластинки-електроди. Зверху черепа нанесений шар поролону для імітації м'яких тканин, зроблена імітація зубних рядів, язика. Поверх поролону нанесена тонка гума для імітації шкірних покривів. За допомогою гнучкого стрижня череп приєднаний до коробки, на якій у вигляді табло винесені назви анестезій. Другим електродом $є$ голка, яка за допомогою дроту також поєднується з табло на коробці. При правильно проведеній анестезії голка торкається електродапластинки у місці виходу нервів. Електричний ланцюг замикається і на табло висвітлюється віконце 3 назвою анестезії, що проводилась.

На цьому тренажері проводиться відпрацювання навичок проведення периферичних і центральних про-

\section{Література}

1. Педагогіка вищої школи (навч. посіб.) [3. І. Курлянд та ін.]. - Київ : Знання, 2007. -495 с.

2. Основи дидактики вищої школи на до-і післядипломній стадіях навчання лікаря-стоматолога / О. О. Тимофеєв, С. В. Вітковська, О. О. Тимофєєв, С. В. Максимча. - К. : відникових анестезій, знаходження місця вколу голки, виправлення руху голки, цільового пункту.

Після того, як кожний студент відпрацює навички проведення інфільтраційної і провідникових анестезій на моделях і тренажері, проводиться розбір неточностей, помилок і позитивних моментів при проведенні анестезій кожним студентом.

Ще одним важливим аспектом при виконанні даної маніпуляції є спілкування з пацієнтом, положення пацієнта у кріслі і т. п. Тому після відробки навичок i умінь на моделях і тренажерах ми у вигляді ділової гри ділимо студентів на пари “пацієнт-лікар", даємо кожній парі конкретні дані (для лікаря - яку анестезію потрібно виконати, для пацієнта - дані про його загальний стан, алергічний фон і т. п.). Студент - “лікар” повинен правильно розташувати студента - "пацієнта" у кріслі, зібрати анамнез і імітувати проведення анестезії. Потім студенти міняються місцями.

Висновок. Проводячи заняття 3 модуля "Методи місцевого знеболення в стоматології” за даною методикою, ми навчаємо студентів не тільки теоретичних знань, але й даємо можливість якісно виконувати мануальні навички при роботі з різними видами шприців, а також відробити навички та вміння проводити інфільтраційну та периферичну і центральну провідникові анестезії.

У студентів розвивається клінічне мислення, вони навчаються проводити розрахунок потрібної дози анестетика для вікових категорій пацієнтів і пацієнтів з різною соматичною патологією.

Науковий світ, 2010.- 110 c.

3. Кононенко Ю. Г. Местное обезболивание в амбулаторной стоматологии / Ю. Г. Кононенко, Н. М. Рожко, Г.П. Рузин. - К. : Книга-плюс, 2001. - 320 с. 